Research Article

\title{
Benthification in the inland water ecosystems of Eurasia, some ecological aspects
}

\begin{abstract}
The changing in the trophic pyramid structure in aquatic ecosystems named as benthification/ contourization is important process the results of which not only affects fishing, but also creates technical interference in cooling reservoirs. We compared the benthification process in natural large Lake Balkhash and artificial cooling pool of Khmelnitsky Nuclear Power Plant on the base of long-term study of phytoplankton, zooplankton, and zoobenthos. The changes of the Balkhash Lake ecosystem that is under invasion of bivalve Monodacna colorata can be divided into two periods:
\end{abstract}

I. Before 1996 with diverse benthic species, and

II. Period of 1996-2012 when was increased the benthos biomass as a result of underutilization by carp of the shellfish as a fodder object.

The benthification process of the Khmelnitsky NPP cooling pool ecosystem is divided its ecosystem functioning into three periods:

i. 1998-2007 before the invasion of zebra mussels and its first period of occupation with developed phytoplankton;

ii. 2008-2011 with benthification caused of Dreissena invasion;

iii. From 2012 until present with restoration of phytoplankton variables. Only with help of the water temperature bioindication we can conclude that the ecosystem response to the thermal impact of second power unit entry is delayed and turns out to be less than the subsequent invasion of the Dreissena.

Keywords: benthos, phytoplankton, nuclear power plant, cooling pool, KhNPP reservoir, Ukraine, Balkhash Lake, Kazakhstan
Volume 2 Issue 7 - 2017

\author{
Barinova SS, ' Krupa EG, ${ }^{2}$ Protasov AA, ${ }^{3}$ \\ Novoselova $\mathrm{TN}^{3}$ \\ 'Institute of Evolution, University of Haifa, Israel \\ ${ }^{2}$ Republican State Enterprise on the Right of Economic Use \\ "Institute of Zoology", Ministry of Education and Science, \\ Kazakhstan \\ ${ }^{3}$ Institute of Hydrobiology of NAS of Ukraine, Ukraine
}

Correspondence: Barinova SS, Institute of Evolution, University of Haifa, Mount Carmel, 199 Abba Khoushi Ave., Haifa 3498838, Israel, Email Sophia@evo.haifa.ac.il

Received: October 31, 2017| Published: November 24, 2017

\section{Introduction}

The phenomenon of changes which are expressed in increase benthic and periphytic primary production over pelagic production in the food web, had been named as process of "benthification" or "contouring"/contourization ${ }^{1}$ which reflect an overall alteration of the aquatic ecosystem function. ${ }^{1-4}$ Increased water transparency after Dreissena polymorpha Pallas 1771 invasion has been favor benthic algal primary production in freshwater systems previously dominated by phytoplankton production as in the Oneida Lake, Naroch Lake, and others. ${ }^{4,5}$ The sun light in the open ecosystems is the overriding factor that determines the distribution and diversity of autotrophes and the dreissenid invasion as mediating factor of water transparency and light penetration increasing is the most important. Therefore the dreissenid invasion to aquatic ecosystems is contributes to benthification in North American lakes. ${ }^{6}$ The principal cause of such shift is considerable increase of water transparency that leads to growth of abundance and bottom autotrophs production and to expansion of habitat by autotrophs and bottom photosynthesis in depth. ${ }^{2}$ Zebra mussel is the important supplier of phosphorus and nitrogen according excretion of them. However during night time, when in filamentous algae congestions the content of oxygen can sharply decrease, ${ }^{7}$ diffusion of phosphorus from bottom sediments to water essentially increases. Thus, system of backward and forward linkages in community (in complete community) promotes activation of biogeochemical cycles within marginal groups. ${ }^{2}$ An obtaining of trustworthy information about their structure and functioning is necessary. But monitoring only allows accumulating data about ecosystem, thus the methodology of estimations of a techno-ecosystems condition, degree of influence of technogenic factors on a live part of all system, influence of last one on environment is necessary. The same can be called for the lake ecosystems because the lakes and lake-type water bodies such as wetlands, estuaries, and reservoirs, including the cooling pool plants are important as sources and collectors of water. Principles of the Water Frame Directive of EEC (WFD-2000) can be applied here. The phytoplankton and zooplankton abundance in the cooling pool at the Khmelnitsky Nuclear Power Plant (KhNPP) was characterized by heterogeneity that because the regulation of the ecosystem and control of major variables are represent rather problem. ${ }^{8}$ The problems of benthification are not only pools ${ }^{2,8}$ but also large lakes like Oneido, Great Lakes in America, and Balkhash, Naroch lakes in Eurasian continent ${ }^{6,9}$ that due this process needing for detail study on different examples. The aim of present study was to find the sufficient relationships between primary and secondary producers of the pool or lake ecosystems during the zoobenthic species invasion that can be monitored in future.

\section{Description of studied sites}

\section{The Balkhash lake}

The Balkhash Lake (Figure 1) is one of the largest lakes within the arid zone of Kazakhstan. ${ }^{9}$ The rivers Ili, Karatal, Aksu, and Lepsy, which flow into the lake from the south, originate in the mountains of the Tian Shan. The Uzynaral Strait divides the lake into two different parts: the Western Balkhash and the Eastern Balkhash. The Balkhash Lake features an increase of total dissolved solids (TDS) in the 
direction from west to east. Increased level of heavy metals in water and soil is caused by the presence of ore deposits in the region as well as anthropogenic pollution of the lake. ${ }^{9}$

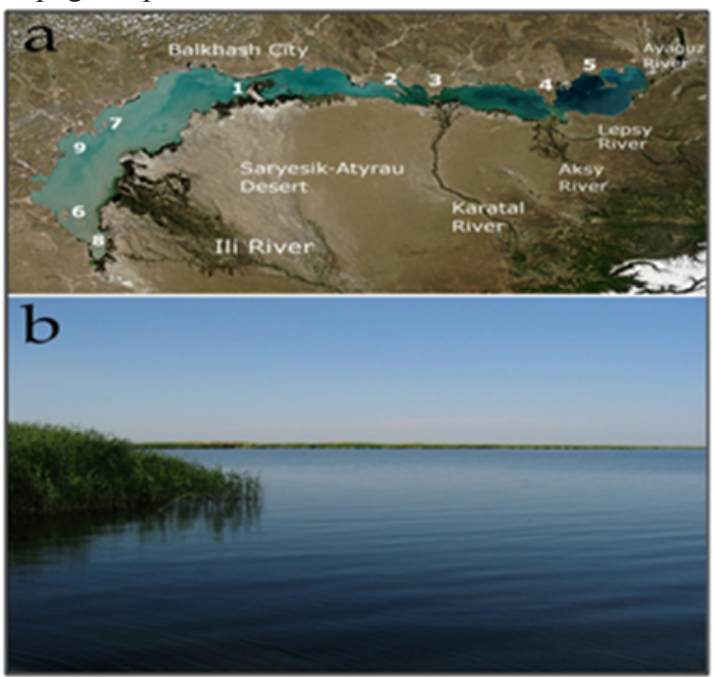

Figure I Map of the Balkhash Lake with the hydrological regions and the falling rivers (a); view of the lake with the macrophytes belt (b).

\section{Khmelnitsky nuclear power plant cooling pool}

The cooling pool at the Khmelnitsky NPP (KhNPP) (Figure 2) is a reservoir filled in 1986 with waters of the Gniloy Rog River as well as with the Goryn' River, and operated from 1987. The area of this pool is $15.4 \mathrm{~km}^{2}$ and the volume is approximately 120 million $\mathrm{m}^{3}$, surface area is $20 \mathrm{~km}^{2}$, the slowness of the coastline is $20.4 \mathrm{~km}$, the average depth is about $6 \mathrm{~m}$ with maximal $12 \mathrm{~m} .{ }^{4} \mathrm{In}$ the north this pool is limited by an earthen dam $6.85 \mathrm{~km}$ long faced with concrete to the bottom (depth, $7-8 \mathrm{~m}$ ), and then $(3 \mathrm{~km})$ with rubble. The water volume in the intake canal is approximately 0.8 million $\mathrm{m}^{3}$. The Zebra mussel (Dreissena polymorpha) spontaneously invaded the cooling pool in 2003-2004. ${ }^{7}$ The problem of the Zebra mussel was increase during next years and with the outbreak of development in 2006-2007 it have a maximal value up to $2 \mathrm{~kg} \mathrm{~m}^{2}$ in benthos and up to $20 \mathrm{~kg} \mathrm{~m}^{2}$ in periphyton in $2008,{ }^{2}$ and then in 2008-2011 decrease. ${ }^{8}$

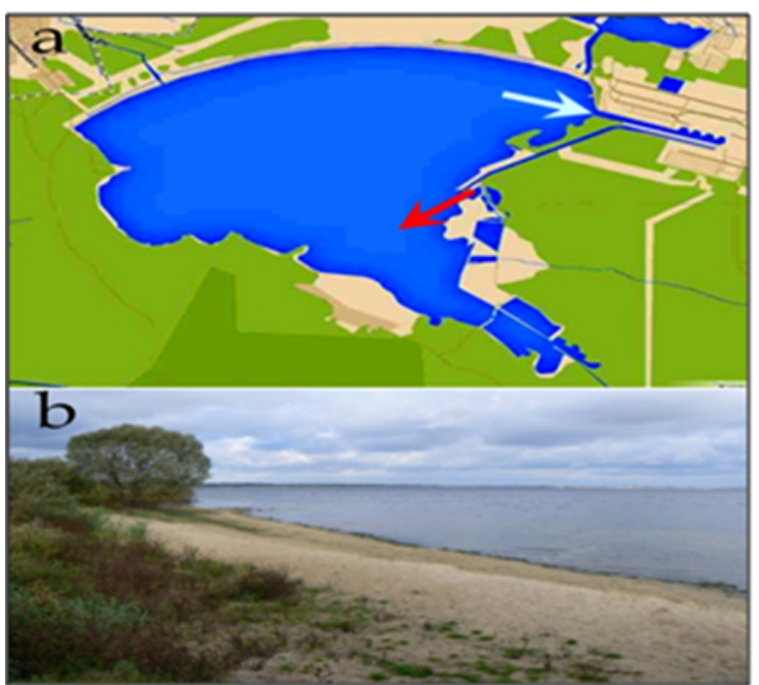

Figure 2 Map of cooling pool at the Khmelnitsky NPP (a) with red arrow for hot water input to the pool, and blue arrow for cold water output; the cooling pool view in August 2014 (b).

\section{Results and discussion}

\section{The Balkhash lake ecosystem long-term dynamic}

Statistically generated maps of water temperature and phytoplankton species richness of the Balkhash Lake in 2004 are represented in Figure 3. The water temperature varied in range 22.6$25.9^{\circ} \mathrm{C}$ and was higher in the central and eastern parts of the lake (Figure 3a). Phytoplankton was represented by 91 species from 9 Divisions and has difference in distribution over the lake (Figure $3 b$ ) with richest communities near the rivers input. The average long-term biomass of phytoplankton in the Balkhash Lake during the period from 1972 to 2012 was $0.94 \pm 0.07 \mathrm{~g} \mathrm{~m}^{-3}$. The biomass value varied within the limits of $0.17-1.86 \mathrm{~g} \mathrm{~m}^{-3}$. The mean annual biomass of zooplankton (1976-2012) reached $1.47 \pm 0.095 \mathrm{~g} \mathrm{~m}^{-3}$, with a range of fluctuations from 0.50 to $3.14 \mathrm{~g} \mathrm{~m}^{-3}$. Cladocera and Copepoda were dominated. The average annual biomass of macrozoobenthos was $8.19 \pm 1.47 \mathrm{~g}$ $\mathrm{m}^{-2}$. The value of the biomass was varied from 1.30 to $49.45 \mathrm{~g} \mathrm{~m}^{-2}$ in different years. The inter-annual dynamics of phytoplankton and zooplankton biomass had the similar orientation (Figure 4). The absence of a statistically significant relationship between the long-term dynamics of phytoplankton and zooplankton is due to a temporary delay in the variability of the second community relative to the first, with a lag of 6-7years. This indicates, on the one hand, the weak influence of the zooplankton community on the quantitative variables of phytoplankton, on the other hand, on the presence of an external factor that induces unidirectional long-term changes in plankton communities.

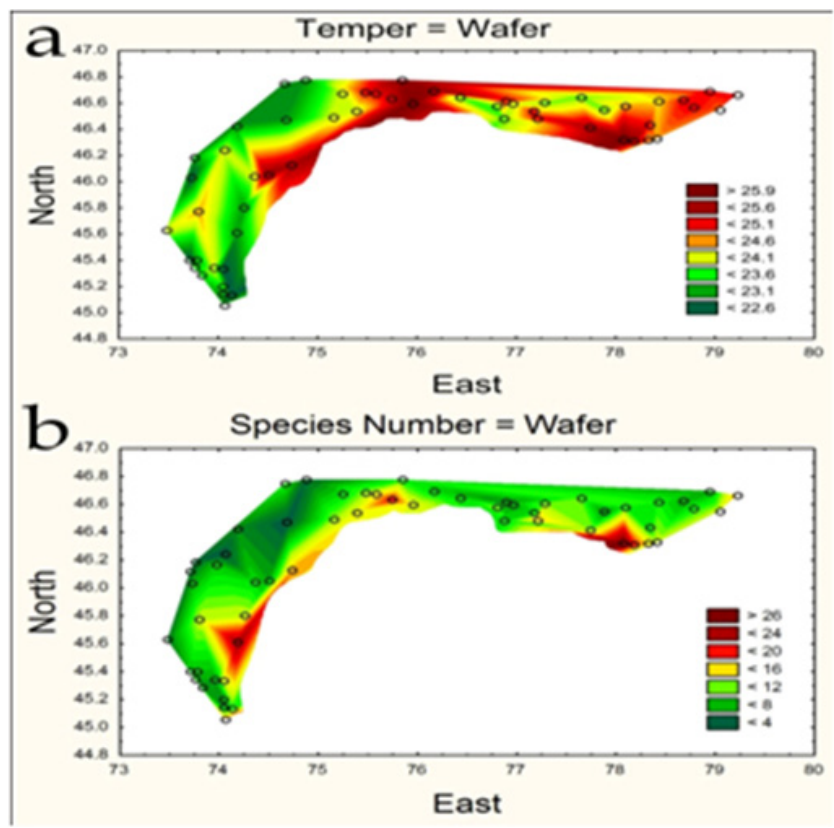

Figure 3 Statistically mapped water temperature (a) and phytoplankton species richness (b) of the Balkhash Lake in 2004.

In the long-term dynamics of phytoplankton of the Lake Balkhash stands out two time intervals: 1976-1995 and 1996-2012. They are divided by a sharp decrease in the total biomass of algal cells at the junction of these intervals. The average annual biomass of phytoplankton in the first two decades was $1.09 \pm 0.09 \mathrm{~g} \mathrm{~m}^{-3}$. In subsequent years, the value of the biomass fell to $0.73 \pm 0.09 \mathrm{~g} \mathrm{~m}^{-3}$. We showed earlier that the controlling clamping on phytoplankton of the Balkhash Lake was provided not only by climatic and environmental factors ${ }^{10-14}$ but mostly by the bivalve Monodacna colorata (Eichwald, 
1829), ${ }^{15}$ whose dietary spectrum is represented by the protists, organic matter, bacteria, and phytoplankton. ${ }^{16}$ Until 1995, the biomass of macrozoobenthos was formed mostly by larvae of Chironomidae, Mysidacea, and Corophiidae. Since 1996, there has been a trend of a sharp increasing in the biomass of the bottom community due to the bivalve Monodacna colorata. The share of Monodacna colorata in the total biomass of macrozoobenthos has increased in recent decades to $75.3-95.6 \%$, while a decrease in the biomass of algal cells. In turn, the restructuring of the bottom community structure is caused by a significant reduction in the commercial herd of benthic fish, mainly carp, the population of which in recent decades is represented mainly by individuals of younger ages. ${ }^{17}$ The total biomass of macrozoobenthos in the period 1996-2012 (17.50 $\left.\pm 3.37 \mathrm{~g} \mathrm{~m}^{-2}\right)$ averaged 4 times increased the value for the previous years $\left(3.53 \pm 0.26 \mathrm{~g} \mathrm{~m}^{-2}\right)$ as a result of underutilization by carp of the shellfish as a fodder object. Therefore, if the biomass of the macrozoobenthos due to the Monodacna colorata persists at a high level, it is to be expected that in a few years the abundancy and biomass of the zooplankton community as a competitive consumer of phytoplankton will also decrease.

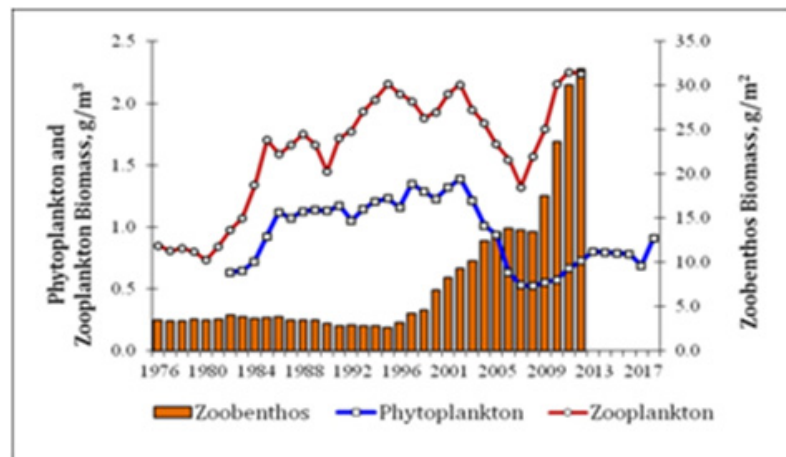

Figure 4 Long-term distribution of phytoplankton, zooplankton, and zoobenthos biomass in the Balkhash Lake in 1976-2017.

\section{The Khmelnitsky NPP cooling pool ecosystem long- term dynamic}

The statistically generated maps $^{8}$ demonstrated decreasing of water temperature in the water flow direction from 26.2 to $22.3^{\circ} \mathrm{C}$ (Figure 5a). Environmental variables besides the water temperature gradient fluctuated in small range. Zooplankton abundance distribution (Figure $5 b)^{8}$ show its preference of water with lower temperature in contrary to phytoplankton. The distribution of plankton was also influenced by technical-caused water circulation and wind currents. ${ }^{2}$ The phytoplankton abundance and biomass were higher in high temperature southern part of the pool. Zooplankton abundance, biomass, as well as the average algal cell volume were highest in the northern part of the pool where the water temperature decreased. ${ }^{2}$ In total, 277 species, represented by 296 intra specific taxa, were found in the phytoplankton of the KhNPP cooling pool, including the nomenclature type of the species that belong to nine divisions. ${ }^{2}$ The abundance of phytoplankton in the KhNPP was characterized by heterogeneity. This applies to both long-term and seasonal dynamics, as well as spatial distribution along the reservoir. Inter-annual dynamics was characterized by a sharp change in the dominant complex. Figure 6 demonstrated impact of the second unit operation to the phytoplankton species richness of the KhNPP cooling pool. The first stage of the ecosystem response was decreasing in algal species richness. But later algal community was partly restored. Phytoplankton species richness was sharply decreased after invasion of zebra mussels in 2003-2004 with the outbreak of development in 2006-2007 (Figure 6) and the autotrophic community processes have shifted into the periphyton (Figure 7) in relation to Dreissena increasing. Phytoplankton was start to increasing in 2009 only with decreasing of Dreissena polymorpha population ${ }^{2,18,19}$ and restored up to previous number with some fluctuation (Figure 6).

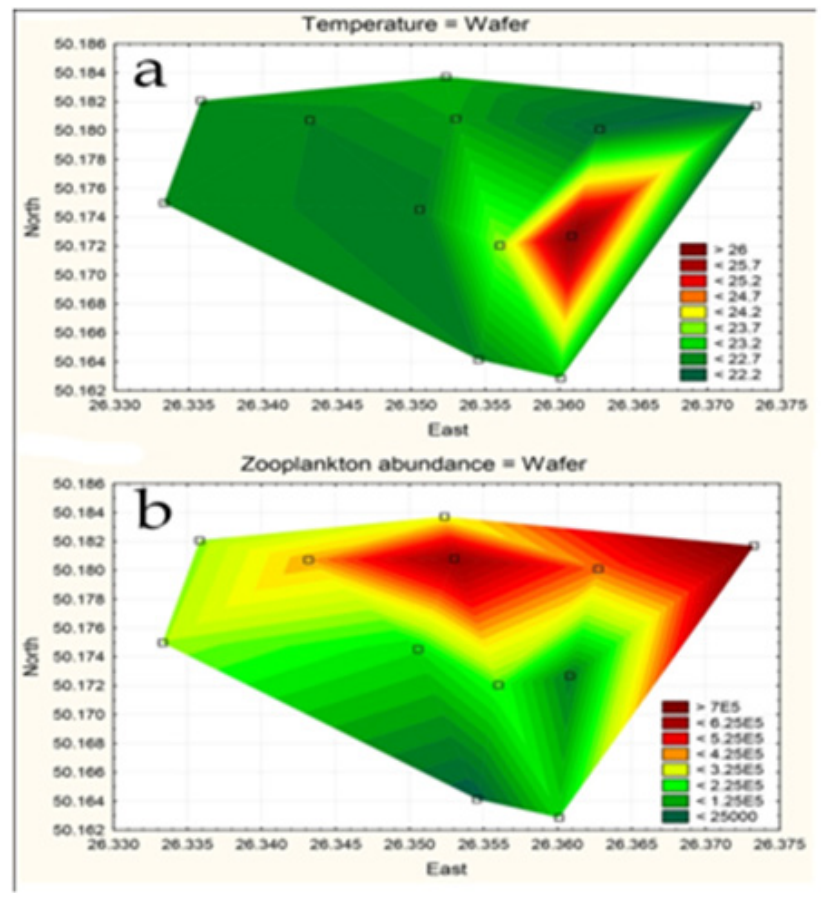

Figure 5 Statistically mapped water temperature and zooplankton abundance in the KhNPP cooling pool surfaces in 2014.

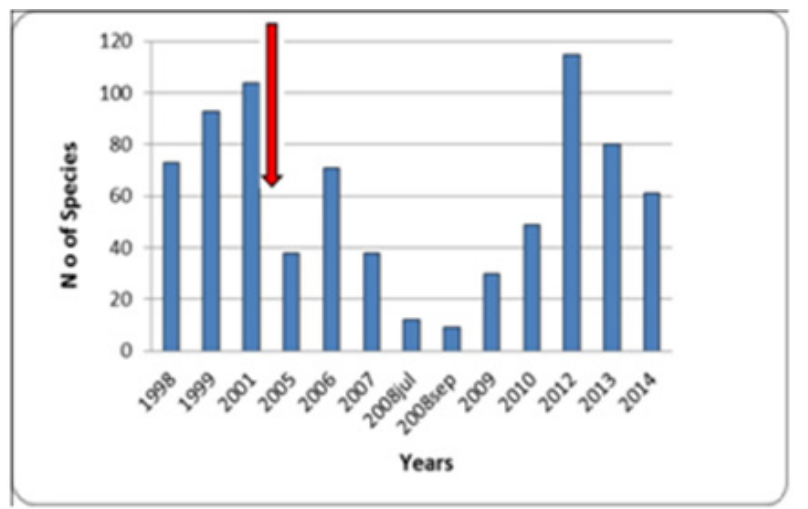

Figure 6 The phytoplankton species richness distribution in the KhNPP cooling pool over 1998-2014. Red arrow is marked of starting time in 2004, where the second power unit was put into operation.

Earlier we characterize the KhNPP cooling pool ecosystem with help of algal bioindication methods. ${ }^{20-22}$ The water temperature indicator species were used for the long-term analysis of the environmental variables fluctuation. ${ }^{23}$ The proportion of temperature indicators was related with the total species richness in phytoplankton. Therefore we has been try to analyze which of water variables or zoobenthos abundance was major factors that impacted KhNPP cooling pool phytoplankton community. Figure 8a show that minimal planktonic species-indicators of water temperature were in the period of fast development of zebra mussels in benthos. Besides the invasion period in 2008-2011 the species richness of algae was similar. It let us to conclude that the hot water input of second power unit was only slightly shifted the richness in the indicators groups but not change the 
community structure. However, Dreissena polymorpha invasion not only decreased species richness (and biomass) in phytoplankton but also made its structure simpler (Figure $8 \mathrm{~b}$ ). The indicators of warm water were enriched of planktonic community in 2012 after "dreissena period" (Figure $8 \mathrm{~b}$ ). But it indicate changes from the temperature temperate species Aulacoseira granulata (Ehrenberg) Simonsen and Trachelomonas hispida (Perty) F.Stein to the community with prevailing of temperate temperature species Aulacoseira granulata and Stephanodiscus hantzschii as well as warm water indicators Staurosira venter (Ehrenberg) Cleve \& JD Möller, Leptolyngbya fragilis (Gomont) Anagnostidis \& Komárek, and Jaaginema geminatum (Schwabe ex Gomont) Anagnostidis \& Komárek. The indicator properties of the last three species are related mostly to organic pollution than warm-water. That can be confirmed also their taxonomic affiliation to the filamenthous Cyanobacteria. Thus, their appearance more shows the saturation of water with organic matter after the death of the bulk of the mollusks than increasing of water temperature.

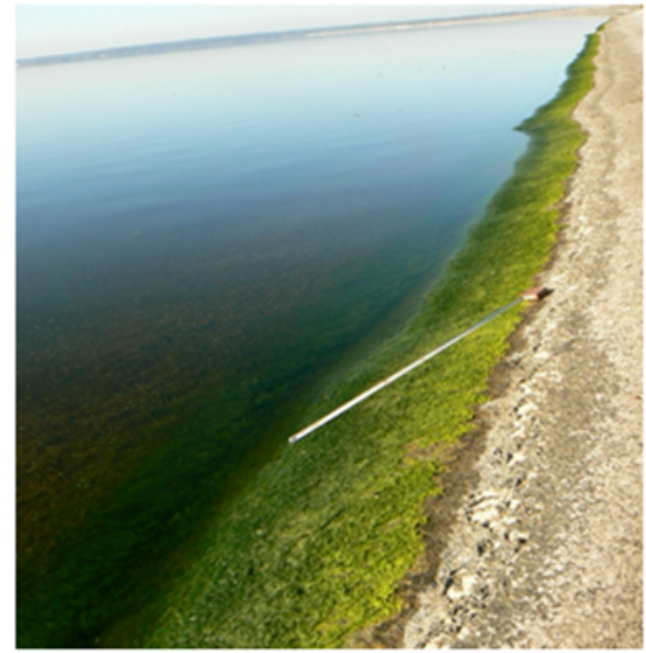

Figure 7 View of the benthification result in the KhNPP cooling pool after invasion of zebra mussels in 2006. The scale bar (white roulette) is Im.

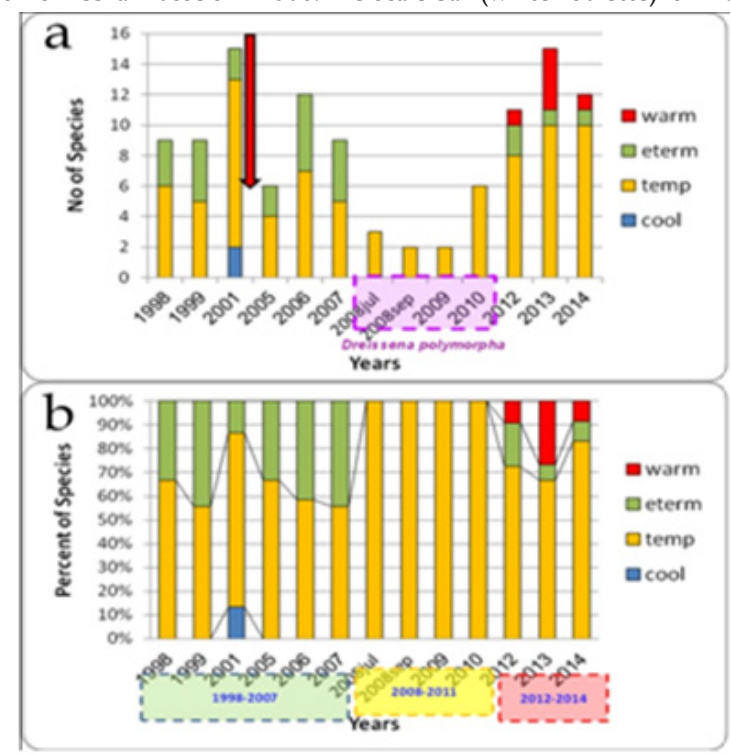

Figure 8 The phytoplankton species indicators of water temperature in the KhNPP cooling pool over 1998-20I4 (a). Red arrow is indicating the second power unit starting time. Percentage of the temperature indicator species groups over the study period (b).

\section{Conclusion}

The benthification/contourization process in the Balkhash Lake was provided by the bivalve Monodacna colorata with two periods. The first was 1976-1995 when the biomass of macrozoobenthos was formed by diverse species. The total biomass of macrozoobenthos in the second period 1996-2012 demonstrated 4 times increased the benthos biomass for the previous years as a result of underutilization by carp of the shellfish as a fodder object. Therefore, if the biomass of the macrozoobenthos in the Balkhash Lake due to the Monodacna colorata persists at a high level, it is to be expected that in a few years the abundancy and biomass of the zooplankton community as a competitive consumer of phytoplankton will also decrease.

As a result of the KhNPP cooling pool study with the help of bioindication of temperature conditions for algae, it was possible to distinguish 3 periods of its ecosystem functioning. The first from 1998 to 2007 before and in the outbreak of zebra mussel's development with developed phytoplankton, in which diatoms and euglenoids dominated. The second in 2008-2011 with benthification/ contourisation caused of Dreissena invasion. The third can be marked from 2012 till present with restoration of phytoplankton that dominated by filamentous Cyanobacteria, and dying out of the major mass of Dreissena. Remarkable, the boundary of 1 and 2 periods does not coincide with the time of the second power unit entry; the ecosystem response to the thermal impact is delayed and turns out to be less than the subsequent invasion of the Dreissena. The massive development of the Dreissena sharply reduced the species richness of planktonic algae. The period after Dreissena is characterized by the restoration of the phytoplankton species richness and the appearance of indicators of warm waters that are also organic pollution indicators. In this research we are tried to illustrate on the different water bodies of Eurasia how adding a single species to a community can greatly modify biodiversity and ecosystem functioning as was demonstrated earlier. ${ }^{24}$ While a comparison of a group of lakes in the Northern Hemisphere, ${ }^{25}$ affected by the invasion of the Dreissena, shows the relationship between water transparency and the invasion period, our studies also reveal the effects of the Dreissena impact. We revealed the periods before, during and after the invasion in the cooling pool of Nuclear power station, and determined that its effect was significantly greater than the effect of temperature impact. It also turned out that strong relations exist not only between producers and consumers, but more clearly negatively correlates the development of plankton communities as a whole with the development of zoobenthos in natural lake. The benthification process research caused by invasion can help to improve the monitoring of controlling factors for the make decision system of the lakes and reservoirs management in purpose to biodiversity conservation and restore.

\section{Acknowledgments}

The work was carried out partly under the project no. 1846/ГФ4 Г.2015-Г2016 for Committee of Science, Ministry of Education and Science, Republic of Kazakhstan "Development of the methods for controlling the ecological state of water bodies in Kazakhstan", "Study of the modern hydro ecological state of fishery water reservoirs and development of biological justifications for the purposefulness and priority of fishery reclamation for conservation and enhancement of the fishery potential of the reservoir". The work was partly supported by the Israeli Ministry of Absorption, and Ministry of Education of Ukraine.

\section{Conflicts of interest}

The authors declare there is no conflict of interests. 


\section{Funding}

None.

\section{References}

1. Protasov AA. Conceptual models of the processes in the aquatic ecosystems. Hydrobiological Journal. 2014;50(1):3-19.

2. Protasov AA. Techno-ecosystem of NPP. Hydrobiology, environment, and ecological assessment. Kiev, Institute of Hydrobiology NASU, Ukraine; 2011.

3. Protasov A, Silayeva A. Marginal groups of hydrobionts in the techno-ecosystems of thermal and nuclear power plants. Institute of Hydrobiology NASU, Ukraine; 2012.

4. Zhu B, Fitzgerald DG, Mayer CM, et al. Alteration of Ecosystem Function by Zebra Mussels in Oneida Lake:Impacts on Submerged Macrophytes. Ecosystems. 2006;9(6):1017-1028.

5. Makarevich TA, Mastitsky SE, Savich IV. Phytoperiphyton on the shells of Dreissena polymorpha (Pallas) in Lake Naroch. Aquatic Invasions. 2008;3(3):283-295.

6. Cecala RK, Mayer CM, Schulz KL, et al. Increased benthic algal primary production in response to the invasive zebra mussel (Dreissena polymorpha) in a productive ecosystem, Oneida Lake, New York. $J$ Integr Plant Biol. 2008;50(11):1452-1466.

7. Velichko IM. Production of periphyton and green filamentous algae. Shallow waters of the Kremenchug reservoir. Kiev: Naukova Dumka; 1979:133-146.

8. Barinova SS, Protasov AA, Novoselova TN. Spatial Analysis of Environmental and Biological Variables in the Techno-Ecosystem of the Khmelnitsky Nuclear Power Plant with New Statistical Approach. MOJ Ecology \& Environmental Sciences. 2017;2(3):1-7.

9. Krupa E, Barinova S, Ponamareva L, et al. Statistical mapping and 3-D surface plots in phytoplankton analysis of the Balkhash Lake (Kazakhstan). Transylv Rev Syst Ecol Res. 2018;20(1):1-16.

10. Krupa E, Slyvinskiy G, Barinova S. The effect of climatic factors on the long-term dynamics of aquatic ecosystem of the Balkhash Lake (Kazakhstan, Central Asia). Adv Stud Biol. 2014;6(3):115-136.

11. Barinova S, Krupa E, Kadyrova U. Spatial dynamics of species richness of phytoplankton of Lake Balkhash (Kazakhstan) in the gradient of abiotic factors. Transylv Rev Syst Ecol Res. 2017;19(2):1-18.

12. Krupa EG, Barinova SS, Tsoy VN, et al. Spatial analysis of hydrochemical and toxicological variables of the Balkhash Lake, Kazakhstan. Res $J$ Pharm Biol Chem Sci. 2017;8(3):1827-1839.
13. Krupa EG, Barinova SS, Tsoy VN, et al. Formation of phytoplankton of Lake Balkhash (Kazakhstan) under the influence of major regionalclimatic factors. Adv Biol Earth Sci. 2017;2(2):204-213.

14. Krupa EG, Barinova SS, Isbekov KB, et al. Influence of chemical water composition on spatial distribution of phytoplankton in the Balkhash Lake (Kazakhstan). Res J Pharm Biol Chem Sci. 2017;8(5):396-411.

15. Krupa EG, Tsoy VN, Lopareva TYa, et al. Long-term dynamics of the hydrobionts of Lake Balkhash and its relationship with environmental factors. Bulletin of the Astrakhan State Technical University, Series: Fisheries. 2013;2:85-96.

16. Alimov AF. Functional ecology of bivalve mollusks. Proceedings of Zoological Institute of the Academy of Sciences of the USSR. Leningrad, Nauka Leningrad Branch. 1981;96:248.

17. Sadyrbaeva NN. Sazan of Lake Balkhash. In:Biodiversity and the rational use of natural resources. Makhachkala, ALEF (IP Ovchinnikov MA); 2013:121-123 (in Russian).

18. Protasov AA, Yurishinets VI. The invasion of Dreissena polymorpha Pallas in the cooling pond of Khmelnitsky NPP. Vesth Zool. 2005;39(5):74.

19. Protasov AA, Sylaieva AA. Contourization and Its Features in Technoecosystems. Inland Water Biology. 2014;7(2):101-107.

20. Protasov AA, Barinova S, Novoselova TN. Characteristics of the ecological state of the cooling reservoir of nuclear power plant on the basis of bioindicative indices of phytoplankton. Hydrobiological Journal. 2017;53(2):3-21.

21. Novoselova TN, Barinova SS. Long-term dynamics of temperature species-indicators in the ptytoplankton of the cooling pond. Proceedings of the III ${ }^{\text {nd }}$ International Conference «Bioindication in monitoring of freshwater ecosystems» 23-27 October 2017, St.-Petersburg, Russia. Institute of Limnology RAS, St.-Petersburg; 2017:226-230.

22. Barinova S. Essential and practical bioindication methods and systems for the water quality assessment. Int $J$ Envir Sci Nat Resources. 2017;2(3):1-11.

23. Barinova S, Fahima T. The Development of the a World Database of Freshwater Algae-Indicators. J Envir Ecol. 2017;8(1):1-7.

24. Simberloff D, Martin JL, Genovesi P, et al. Impacts of biological invasions:what's what and the way forward. Trends Ecol Evol. 2013;28(1):58-66

25. Mayer CM, Burlakova LE, Eklöv P, et al. The benthification of freshwater lakes:exotic mussels turning ecosystems upside down. In:TF Nalepa and DW Schloesser (Eds,). Quagga and zebra mussels:biology, impacts, and control (2 ${ }^{\text {nd }}$ edn.), CRC Press, Boca Raton, FL, USA; 2014:575-585. 